\title{
The Use of Generative Learning Model in Improving Students' Understanding of Mathematical Concepts of Al-Azhar 19 Islamic High School
}

\section{Andri Kosiret (D) | Fariani Hermin Indiyah (D) | Dwi Antari Wijayanti}

How to cite : Kosiret, A., Indiyah, H., F., \& Wijayanti, D,. A.,. Peningkatan Kemampuan Pemahaman Konsep Matematis Siswa SMA Islam Al-Azhar 19 Dengan menggunakan Model Pembelajaran Generatif. International Journal of Progressive Mathematics Education. 1(1).1626.https://doi.org/10.22236/ijopme.v1i1.6593

To link to this article : https://doi.org/10.22236/ijopme.v1i1.6593

(C2021. The Author(s). This open access article is distributed under a Creative Commons Attribution (CC BY-SA) 4.0 license.

Submit your paper to this journal




\title{
The Use of Generative Learning Model in Improving Students' Understanding of Mathematical Concepts of Al- Azhar 19 Islamic High School
}

\author{
Andri Kosiret $(\mathbb{D} 1$, Fariani Hermin Indiyah² $₫(\mathbb{D}$, Dwi Antari Wijayanti
}

Received: December 23, 2020 Accepted: March 1, 2021 Published Online: March 11, 2021

\begin{abstract}
.
Background. Distance learning during the COVID-19 pandemic has changed the landscape of mathematics learning as a whole. One of the mathematics learning models that offer new concepts in distance learning is generative learning model. The Aim of the Research. This study will evaluate the effectiveness of the implementation of generative learning models in improving students' mathematical understanding abilities. The appropriate research method to test the effectiveness is quasi-experimental design because the class being experimented with is not changed, so that it does not have much effect on overall learning stability. The research sample used cluster random sampling technique where class X MIPA 3 was the experimental class while class $X$ MIPA 2 was the control class. The research instrument used was a test of students' ability to understand mathematical concepts in the material of Logarithmic Equations as many as seven essay questions. Conclusion. There is an effect (high) of the generative learning model on the ability to understand students' mathematical concepts applied to the distance learning system at Al-Azhar 19 Ciracas Islamic Senior High School logarithmic equation material with a significance level of $a=0.05$. Contribution. This study offers a new concept for the application of distance learning mathematics by implementing a generative learning model which in this study has contributed positively to student understanding.
\end{abstract}

Keywords: Generative Learning Model, Distance Learning, Ability to Understand Mathematical Concepts

(c) (1) (2) 2021. The Author(s). This open access article is distributed under a Creative Commons Attribution (CC BY-SA) 4.0 license.

Andri Kosiret

andri.kosiret@unj.ac.id

$\triangle$ Fariani Hermin Indiyah

fariani.indiyah@unj.ac.id

Dwi Antari Wijayanti

dwi.antari@uni.ac.id

1 Program Studi S1 Pendidikan Matematika, Universitas Negeri Jakarta, Indonesia 


\section{Introduction}

Mathematics is empirically proven to play an essential role in the educational process both as a direct or indirect object (Asempapa, 2015; Maracci, 2008). The learning process of mathematics in practice has a standard of abilities in supporting mathematics learning, consisting of problem-solving skills, mathematical reasoning abilities, mathematical proofs, mathematical communication, mathematical connections, and mathematical achievement (Rustina \& Anisa, 2018; Satriawati et al., 2018). In learning mathematics, understanding a mathematical concept is the beginning of various doors for solving mathematical problems. Students who have understood a mathematical concept well will find it easier to solve math problems (Rahmi, 2021). Moreover, students understand various mathematical concepts well and have the ability to relate mathematical concepts. It is fundamental in mathematics learning activities.

In mathematics learning, understanding a concept becomes a fundamental element in the learning process (Ainley \& Ainley, 2011; Tan \& Ang, 2016). Students who can understand mathematical concepts well will find it easier to solve mathematical problems. The ability to implement mathematical concepts in a problem plays a crucial role in supporting the solving of a given mathematical problem. In understanding mathematical concepts properly, students must have several important things, including; (1) the object that is the goal, (2) connecting between objects that have the same characteristics, (3) understanding well the correlation with other objects that do not have the same characteristics, and (4) dual relation with other objects that have the same characteristics, (5) the relationship with objects in other theories (Anggar Murizal, 2012).

However, this contradicts the facts in schools. Based on research studies showing that the ability of students to understand mathematical concepts in Indonesia is still low. The results of the Trends in International Mathematics and Science Study (TIMSS) survey in 2015 shows that the mathematical ability of Indonesian students was still very low, as seen from the average score, which made Indonesia ranked 45 out of 50 participating countries (Kemendikbud, 2018). The factors that make Indonesia's ranking below have various factors. Compared with the assessment conducted by TIMSS, most students do not have strong abilities in remembering, explaining facts, linking mathematical concepts, and modeling a problem mathematically. Students who have criteria according to TIMSS are still sporadic. It is because students still memorize mathematical concepts compared to understanding mathematical concepts well.

Based on the results of observations and interviews with mathematics teachers who teach, the students' ability to understand mathematical concepts at SMA Islam Al-Azhar 19 Ciracas is classified as low. This is reinforced by the daily assessment data of students of class X MIPA regarding the ability to understand mathematical concepts, namely; in class X MIPA 1, there are 12 students whose scores for understanding mathematical concepts are above the minimum completeness criteria of 17 students, class X MIPA 2 only 12 students who score comprehension abilities. The mathematical concept is above the minimum completeness criteria of 19 students. In class X MIPA 3 , there are 14 students whose ability to understand mathematical concepts is above the minimum completeness criteria of 18 students.

One of the factors that influence the students' shared understanding of mathematical concepts at Al-Azhar 19 Ciracas Islamic High School is that the learning model applied by the teacher still uses the conventional learning model, only in the online implementation. The teaching system applied by the teacher is only repetitive, and there is very little creativity in developing the art of teaching. This learning does not allow students to build, create, and communicate ideas that students have in solving a mathematical problem (Gustia et al., 2021; Yuningsih et al., 2021). In addition, the factor of student knowledge who has not mastered the material beforehand also affects the process of answering questions and learning mathematics.

Given that learning is a critical element of educational success, the suitable learning model is needed to improve students' ability to understand mathematical concepts (Maulidiya et al., 2018). The selection of the suitable learning model supports the creation of more effective mathematics learning. The model in question must make students actively involved in finding knowledge and building concepts from the subject matter. In mathematics learning, student activity in learning plays a role in improving the quality of learning and provides opportunities for students to develop in building sustainable mathematical knowledge. Active mathematics learning makes students 
happier and impacts students' mentality in building self-confidence in the learning process (Alim et al., 2016; Alves et al., 2016; Rozgonjuk et al., 2020).

The learning model that emphasizes the activeness of students in building concepts is a generative learning model. The generative learning model emphasizes the role of students to construct their knowledge independently. Based on the initial knowledge, they already have and actively participate in the learning process (Fiorella \& Mayer, 2016). The generative mathematics learning model consists of four learning stages including, first, exploration in which the teacher does not directly teach the material to be delivered in class but begins learning mathematics by exploring various simple concepts that exist in everyday life (Ferrer-Torregrosa et al., 2016; Rafiee \& AbbasianNaghneh, 2020). Students are invited to think about different things related to the mathematical concepts to be taught. Second, focusing where the teacher asks students to focus on something related to the concepts being taught. After exploring various things, students are asked to minimize what has been studied so that mathematics learning is more focused (Nurjamil et al., 2017; Thachasongtham et al., 2013). Third, the teacher's challenge gives a challenging math problem because the problem given cannot be solved. Fourth, the application of concepts is an essential part of the generative mathematics learning model (Thachasongtham et al., 2013; Yoshida et al., 2013). At this stage, students need to understand well the mathematical concepts that have been learned in the previous stage. By understanding mathematical concepts well, students can easily participate in learning the implementation of these mathematical concepts (Li, 2016).

Through the implementation of a generative learning model, students can participate actively in learning to have the knowledge, abilities, and skills to build their knowledge independently. By linking prior knowledge that has been previously owned with the concepts being studied, students can finally construct new knowledge (Anderman, 2010; Wittrock, 1974). Furthermore, in 2020 the world will experience the Covid-19 pandemic. Almost all countries have been affected by the covid-19 pandemic, including Indonesia. Indonesia began to be attacked by the Covid19 outbreak in early 2020, to be precise, on March 2, 2020. Over time, the outbreak has spread to all regions in Indonesia. It prompted the government to issue policies to work from home, study from home, and worship at home only. The existence of this policy causes students to learn from home, meaning that schools will implement distance learning. Distance learning is a learning approach that does not meet face to face in class. Distance learning can be used in these conditions because it is internet-based, which means there is no need to come to class (Yaumi, 2007). The implementation of distance learning (PJJ) has also been implemented at Al-Azhar 19 Ciracas Islamic High School.

\section{Method}

\subsection{Research Design}

In evaluating the effectiveness of the generative learning model, this study uses a quantitative research method using a quasi-experimental design. This study has two research groups: the experimental class, where the teacher teaches mathematics learning using a generative learning model. In this control class, the teacher provides mathematics learning as in previous days. In practice, this study uses distance learning. This is due to government restrictions related to face-to-face learning to reduce the spread of COVID-19. The research design was used to evaluate the effectiveness of generative learning models to increase students' ability to understand mathematical concepts. In achieving this goal, this study chooses the Posttest-only Control Design because only the posttest will be calculated to compare the effectiveness of the generative learning model. The research design can be seen in Table 1, as follows;

\subsection{Sample}

This research is conducted at SMA Islam Al-Azhar 19 Ciracas, with a population of all class X MIPA students in the academic year 2020/2021 consisting of three classes. Sampling in this study is carried out using the cluster random sampling technique, namely taking members of the population at random without paying attention to the 
level in the population. Samples are from class X MIPA 3 with a total of 30 students as the experimental class and class X MIPA 2 with a total of 30 students as the control class. From a total of 60 students, this study also categorized three aspects, namely students' mathematical abilities, gender, and learning tools used by students during the distance learning process. Based on the collected data, there are 25 students with high mathematical abilities, 20 students with moderate mathematical abilities, and 15 students with low mathematical abilities. In terms of gender, the population of female students, amounting to 34 students, is more than that of male students, which amounted to 26 students.

\begin{tabular}{|c|c|c|}
\hline \multicolumn{3}{|c|}{ Table 1. Demographics Sample } \\
\hline Category & Label & Total \\
\hline \multicolumn{3}{|c|}{ Students Mathematical Ability } \\
\hline High & $\mathrm{Ti}$ & 25 \\
\hline Moderate & $S$ & 20 \\
\hline Low & $\mathrm{R}$ & 15 \\
\hline \multicolumn{3}{|l|}{ Sex } \\
\hline Male & $\mathrm{L}$ & 26 \\
\hline Female & $P$ & 34 \\
\hline \multicolumn{3}{|l|}{ Learning Tools Used } \\
\hline Handphone & A & 2 \\
\hline Tablet & B & 4 \\
\hline Laptop and handphone & C & 48 \\
\hline Laptop & $\mathrm{D}$ & 6 \\
\hline
\end{tabular}

The data used in this study is the daily assessment data of the exponential equation material. The daily assessment value is used as data to test data analysis before treating experimental class and control class. Then, the test of the ability to understand mathematical concepts is used in seven essay questions to measure the ability of students to understand mathematical concepts after being given treatment. The test questions for the ability to understand the concepts given include: (1) restating a concept, (2) classifying objects according to specific properties according to examples, (3) giving examples and not examples of concepts, (4) presenting concepts in various forms mathematical representation, (5) developing necessary or sufficient conditions of a concept, (6) applying concepts or algorithms to problem-solving, (7) using and utilizing and selecting specific procedures or operations.

Before the instrument is used in this study, it is necessary to validate the content and construct by experts, namely the mathematics education lecturer at the State University of Jakarta and the teacher school of mathematics subject. Then, the questions that experts have validated are tested on students to determine their empirical validity and reliability. The results of content validation, construct, and empirical tests of the ability to understand mathematical concepts state that the test instrument is valid and the reliability test. Therefore, the test instrument for understanding mathematical concepts is appropriate for use in this study.

\subsection{Data Analysis Technique}

The data analysis technique used in this study is the prerequisite test using the normality test and the homogeneity test. Before the treatment, the normality test uses the Liliefors test, while the normality test after treatment uses the Kolmogorov Smirnov test. For the homogeneity test before treatment using the Bartlett test, after treatment using the Fisher test (Sudjana, 2005). In addition, hypothesis testing in this study is carried out using statistical test techniques by the distribution obtained. After the normality and homogeneity are known, testing the research hypothesis is tested using the t-test. The statistical hypotheses use in this study is: 


\section{Finding and Discussion}

\subsection{Research Finding}

In testing normality, this study uses the Kolmogorov Smirnov test because this test is empirically proven to provide results that indicate that the distribution of samples can be normally distributed. The results of the calculation of the experimental class show that $D_{\text {count }}=0,114$, while for $D_{\text {table }}$ that is seen in the critical value of the Kolmogorov Smirnov test with a significance level of $5 \%$ and a sample size of 30 students, namely 0,242 . Thus, the value of $D_{\text {count }}$ is less than $D_{\text {table }}(0,114<0,242)$ then $H_{0}$ is accepted. These results prove statistically that the population in the experimental class is normally distributed.

\begin{tabular}{l|c|c|c|c|c}
\multicolumn{7}{c}{ Table 2. Normality Test Results After Treatment } \\
\hline Class & $\mathbf{n}$ & Significance Level & $\mathbf{D}_{\text {count }}$ & $\mathbf{D}_{\text {table }}$ & Conclusion \\
\hline Experiment & 30 & $5 \%$ & 0,114 & 0,242 & Normally Distributed \\
\hline Control & 30 & $5 \%$ & 0,143 & 0,242 & Normally Distributed \\
\hline
\end{tabular}

The results of the calculation in the control class obtained the value of $D_{\text {count }}=0,143$, while for $D_{\text {table }}$ which is seen in the critical value of the Kolmogorov Smimov test with a significance level of $5 \%$ and a sample size of 30 students, namely 0,242 . Thus, the value of $\mathrm{D}_{\text {count }}$ less than $\mathrm{D}_{\text {table }}(0,142<0,242)$ then $H_{0}$ is accepted, so the data in the control class is data obtained from a normally distributed population. Based on table 2, it can be shown that the experimental class and control class data are normally distributed. After knowing that the experimental and control classes are normally distributed, the next step is to carry out the homogeneity test using Fisher test. The main purpose of using this homogeneity test is to determine whether or not the two distributions are the same. The results of the homogeneity test can be seen in Table 3, as follows;

\begin{tabular}{c|c|c|c|c|c}
\hline \multirow{6}{*}{ Class } & $\mathbf{n}$ & $\begin{array}{c}\text { Variance } \\
\left(\boldsymbol{s}^{\mathbf{2}}\right.\end{array}$ & Count & Table $(\boldsymbol{\alpha}=\mathbf{5 \%})$ & \multirow{2}{*}{ Conclusion } \\
\cline { 5 - 5 } & & 85,540 & 0,257 & 1,861 & \multirow{2}{*}{ Accepted $\mathrm{H}_{0}$} \\
\hline Experiment & 30 & 30 & 333,098 & & \\
\hline Control & 30 &
\end{tabular}

Based on the calculation results obtained $F_{\text {count }}$ of 0,257 . At a significant level of 0,050 the $F_{\text {tabel }}$ is 1,861 . Because $F_{\text {count }}=0,257<1,861=F_{\text {table }}, \mathrm{H}_{0}$ is accepted. Thus it can be concluded that the two classes have homogeneous conditions, so the t-test formula used is the t-test formula with the same variance.

\begin{tabular}{c|c|c|c}
\hline \multicolumn{4}{c}{ Tabel 4. Two Class Equation Test Results After Treatment } \\
\hline Degree of Freedom (df) & $\mathrm{t}_{\text {count }}$ & $\mathrm{t}_{\text {table }}(\alpha=5 \%)$ & Conclusion \\
\hline 58 & 2,248 & 2,002 & Rejected $\mathrm{H}_{0}$ \\
\hline
\end{tabular}

Based on the results of the average calculation between the experimental class and the control class, it is obtained that $t_{\text {count }}=2,248$ and $t_{1-\frac{1}{2} \alpha}=2,002$ with $t_{\text {count }}>t_{1-\frac{1}{2} \alpha}$, so that $H_{0}$ is rejected. These results indicate that students who have been given different treatments show a difference in the average score of the test scores for the ability to understand mathematical concepts in the experimental class and the control class. The results of the average score of students 'ability to understand mathematical concepts in the experimental class proved that the generative learning model has a positive tendency in increasing students' understanding ability. With the various limitations of conducting research conducted online, this study still shows that teaching methods 
that adapt to current needs are empirically proven to improve mathematical comprehension skills. In its implementation, the researchers noticed that in the exploration stage, the students feel delighted. It is because students are invited to participate in learning actively. Students are asked either in groups or individually to explore logarithmic material. Some of the questions raised by students during the learning process are also very challenging. Teachers and researchers feel that the questions posed are very implementative of logarithms so that researchers answer with the knowledge they already have. However, it turned out that the answers raised by the researchers become the main trigger for these students to continue to be more actively involved in the learning process.

Table 4 also shows the effect of implementing the generative learning model on understanding students' mathematical concepts at Al-Azhar 19 Ciracas Islamic Senior High School with a significance level of $\alpha=0,05$. In applying this generative learning model, researchers collaborate with teachers. This collaboration turns out to have a very significant impact on the learning process. It is evidenced by the results of the calculation of the amount of influence based on Cohen's test, which is 2.265 . These results can be interpreted that the effect of the generative learning model that has been carried out in class XI at Al-Azhar 19 Islamic High School is in the high category.

\subsection{Discussion}

In this study, researchers use logarithmic equation material in the odd semester of class X. Before learning; firstly, the researchers make a lesson plan design that is used at every meeting in the experimental class. In compiling the learning design, researchers pay attention to all stages of the generative learning model, consisting of 4 stages (Wena, 2012; Wittrock, 1974). The researcher clearly describes how the exploration stage is carried out in mathematics learning even though the learning is carried out virtually. Students are asked to participate actively in the learning process. Teachers are also designed to perform periodic checks on virtual classrooms. This is done as part of the control over online mathematics learning.

Researchers do the same thing with learning in the control class, where the researchers use the learning implementation plan that has been made by the subject teacher. The fundamental difference between the current learning design and face-to-face learning is that it adapts to virtual meetings that many teachers in previous lessons have implemented. Furthermore, this learning implementation plan is used by subject teachers as a guide in carrying out the learning process in the classroom. The learning process uses the Generative Learning Model, which is applied to the distance learning implementation system. In practice, the generative learning model has four stages: exploration, focus, challenge, and implementation of mathematical concepts (Wena, 2010).

From the learning activities carried out in generative model learning, it can be seen that students are expected to be able to express their concepts accompanied by arguments to support the concept. The ability of students to provide arguments shows the mathematical understanding that has been built in students (Selçuk et al., 2010). In practice, students can argue with other students within the limits of learning mathematics. When one student gives an opinion, other students can give either positive or negative responses but in constructive discussion rules. With the active participation of students in discussions, learning becomes more focused on students, so that the role of the teacher as a facilitator is expected to be more developed. This has a positive effect because it is hoped that students will appreciate other people's concepts and are accustomed to expressing their opinions without being burdened with a sense of wanting to win or lose.

The relationship between applying the generative learning model to the conceptual understanding ability is illustrated by the process carried out by teachers and students at each stage of the model. In the preliminary stage, the teacher stimulates students to express opinions and formulate problems regarding the problems given. Students then orientate the knowledge they have previously gained from daily experience or previous learning to formulate ideas in making hypotheses. After obtaining ideas, students classify these ideas together with the teacher. At the focusing stage, the teacher guides students to determine the context of the problem utilizing a scientific process or through testing. Students test the ideas they have obtained against a problem so that it can be seen how these ideas can solve the problem. After that, students present the results of their thoughts in a class forum. Entering the challenge stage, the teacher facilitates students to respond to presentations from other students, then directs an exchange of ideas at that time. Discussions carried out in class have not only a positive impact on the exchange of 
knowledge of mathematical concepts that students already have but also provide sustainable self-confidence for students who can express their opinions (Brennan \& Hugo, 2016; Jameson, 2014; Umam et al., 2019 ).

In the last stage, namely the application stage, the teacher provides another simple problem for the students to solve. Students are expected to be able to solve practical problems given by using concepts that have been built in the previous stages. After that, students present their answers in front of the class. The ability of students to communicate in front of the class not only develops active communication skills but also provides opportunities for students to appear in front of many people. This is of course very positive for the mental development of students. The presentation is not limited to confirmation from the teacher whether the answer is appropriate or not, but also encourages other students to argue that the results that have been done are not appropriate (Anderman, 2010; le Roux \& Nagel, 2018). At the end of generative learning, the teacher guides and directs students to make final conclusions on the material that has been taught. Technically, the teacher can ask several students to make conclusions and end with a brief explanation from the teacher. However, suppose the learning time can last longer. In that case, the teacher can ask all students to express their opinions about the conclusions on the material, then end with the conclusions put forward by the teacher regarding the material that has been delivered. This study combines the two technical conclusions to adjust to the time allocation and internet quota that are owned by the students.

\section{Conclusion}

The results have shown that the ability to understand mathematical concepts of students who learn using generative learning models gets more satisfying results when compared to classes that are not taught with generative learning models. This research study shows that students have started to be invited to think about the subject matter being taught at the exploration stage. Active student interest in learning supports the creation of a sustainable motivation to learn mathematics. This has a very positive impact on the various learning processes that take place. By being asked to explore, students who can search for various sources with an internet connection have indirectly learned the material on logarithmic equations. With active student participation, distance learning with a generative learning model will encourage students to explore various things about the material to be studied.

This is different from learning in the control class, where the teacher continues to behave with the concept of face to face virtually. Students' potential absence from virtual learning is a significant obstacle because teachers cannot control student attendance. This difficulty has a massive impact on the evaluation of improving students' mathematical conceptual understanding. With the difficulty of controlling student activities during online learning, there is an opportunity for students to look for activities other than learning by opening websites that are within reach of the internet. Based on the two results of application in the control and experimental classes, this study can explicitly conclude that generative learning model can improve the students' ability to understand mathematical concepts of Al-Azhar 19 Ciracas Islamic High School students on logarithmic equations.

\section{Upcoming research}

This study evaluates mathematics learning with a generative model, which is limited to two classes within the scope of the school with 60 students participating in the study. The limited time of the research coupled with social restrictions that impact distance learning are the main considerations for researchers to apply the evaluation of generative learning models on a limited scale. The application of the generative learning model in this study is still limited to one mathematics subject matter in class XI. In the following research, it is expected to evaluate the implementation of a generative learning model with a larger population by knowing the effectiveness of the generative learning model with a larger population so that the results can offer an alternative solution for learning mathematics in the future. 


\author{
Authors Identity \\ Andri Kosiret \\ Email: andri.kosiret@unj.ac.id \\ Fariani Hermin Indiyah \\ Email: : fariani.indiyah@uni.ac.id \\ Dwi Antari Wijayanti \\ Email: ishaq_nuriadin@uhamka.ac.id
}

\title{
Conflict of Interest
}

The authors state there is no conflict of interest

\section{Citation information}

Cite this article as: Kosiret, A., Indiyah, H., F., \& Wijayanti, D,. A.,. Peningkatan Kemampuan Pemahaman Konsep Matematis Siswa SMA Islam Al-Azhar 19 Dengan menggunakan Model Pembelajaran Generatif. Journal of Progressive Mathematics Education. 1(1).16.26. https://doi.org/10.22236/ijopme.v1i1.6593.

\section{References}

Ainley, M., \& Ainley, J. (2011). Student engagement with science in early adolescence: The contribution of enjoyment to students' continuing interest in learning about science. Contemporary Educational Psychology, 36(1), 4-12. https://doi.org/10.1016/j.cedpsych.2010.08.001

Alim, E. S., Umam, K., \& Wijirahayu, S. (2016). The implementation of blended learning instruction by utilizing wechat application. ICCE 2016 - 24th International Conference on Computers in Education: Think Global Act Local - Workshop Proceedings.

Alves, M., Rodrigues, C. S., Rocha, A. M. A. C., \& Coutinho, C. (2016). Self-efficacy, mathematics' anxiety and perceived importance: an empirical study with Portuguese engineering students. European Journal of Engineering Education, 41(1), 105-121. https://doi.org/10.1080/03043797.2015.1095159

Anderman, E. M. (2010). Reflections on Wittrock's generative model of learning: A motivation perspective. Educational Psychologist, 45(1), 55-60. https://doi.org/10.1080/00461520903433620

Asempapa, R. S. (2015). Mathematical Modeling: Essential for Elementary and Middle School Students. Journal of Mathematics Education (C) Education for All Spring, 8(1), 16-29.

http://educationforatoz.com/images/Asempapa_2015-Spring_.pdf

Brennan, R. W., \& Hugo, R. J. (2016). A Self-Efficacy Survey for Engineering Graduate Attributes Assessment. 13th International CDIO Conference. http://www.cdio.org/files/document/cdio2017/36/36_Final_PDF.pdf 
Ferrer-Torregrosa, J., Jiménez-Rodríguez, M. Á., Torralba-Estelles, J., Garzón-Farinós, F., PérezBermejo, M., \& Fernández-Ehrling, N. (2016). Distance learning ects and flipped classroom in the anatomy learning: Comparative study of the use of augmented reality, video and notes. BMC Medical Education, 16(1), 1-9. https://doi.org/10.1186/s12909-016-0757-3

Fiorella, L., \& Mayer, R. E. (2016). Eight Ways to Promote Generative Learning. Educational Psychology Review, 28(4), 717-741. https://doi.org/10.1007/s10648-015-9348-9

Gustia, H., Juwita, H., \& Siswanto, J. (2021). Efektivitas Model Pembelajaran Make A Match terhadap Hasil Belajar pada Materi Balok Kelas VIII. Jurnal Riset Pendidikan Matematika Jakarta, 3(1), 1926.

Jameson, M. M. (2014). Contextual Factors Related to Math Anxiety in Second-Grade Children. Journal of Experimental Education, 82(4), 518-536. https://doi.org/10.1080/00220973.2013.813367

le Roux, I., \& Nagel, L. (2018). Seeking the best blend for deep learning in a flipped classroom - viewing student perceptions through the Community of Inquiry lens. International Journal of Educational Technology in Higher Education, 15(1). https://doi.org/10.1186/s41239-018-0098-x

$\mathrm{Li}, \mathrm{C} . \mathrm{H}$. (2016). From adaptive to generative learning in small and medium enterprises-a network perspective. Journal of Global Entrepreneurship Research, 6(1). https://doi.org/10.1186/s40497016-0054-y

Maracci, M. (2008). Combining different theoretical perspectives for analyzing students' difficulties in vector spaces theory. ZDM - International Journal on Mathematics Education, 40(2), 265-276. https://doi.org/10.1007/s11858-008-0078-z

Maulidiya, D., Susanta, A., \& Irsal, N. A. (2018). Model Investigasi Berbantuan Geogebra pada Geometri Bidang Abstrak. Jurnal Riset Pendidikan Matematika Jakarta, 1(2013), 15-21. http://journal.unj.ac.id/unj/index.php/jrpmj/article/view/4969/3664

Nurjamil, D., Kurniawan, D., Studi, P., Matematika, P., \& Siliwangi, U. (2017). Pendekatan scientific berbantuan Geogebra untuk meningkatkan. Jurnal Riset Pendidikan Matematika Jakarta, 3(1), 1320. http://journal.unj.ac.id/unj/index.php/jrpmj/article/view/4972/3666

Rafiee, M., \& Abbasian-Naghneh, S. (2020). Willingness to Write (WTW): Development of a model in EFL writing classrooms. Cogent Education, 7(1), 0-16. https://doi.org/10.1080/2331186X.2020.1847710

Rahmi, A. (2021). Tahap Preliminary Research Pengembangan Media Pembelajaran Berbasis Komputer pada Materi Transformasi SMA / MA. Jurnal Riset Pendidikan Matematika Jakarta, 3(1), 14-18.

Rozgonjuk, D., Kraav, T., Mikkor, K., Orav-Puurand, K., \& Täht, K. (2020). Mathematics anxiety among STEM and social sciences students: the roles of mathematics self-efficacy, and deep and surface approach to learning. International Journal of STEM Education, 7(1). https://doi.org/10.1186/s40594-020-00246-z

Rustina, R., \& Anisa, W. N. (2018). Kontribusi Model Problem Based Learning terhadap Peningkatan 
Kemampuan Koneksi dan Pemecahan Masalah Matematik. Jurnal Riset Pendidikan Matematika Jakarta, 1(1), 8-14.

Satriawati, G., Musyrifah, E., \& Purwanto, S. (2018). Pengaruh Strategi Pembelajaran Active Knowledge Sharing t terhadap Kemampuan Komunikasi Matematik Siswa. Jurnal Riset Pendidikan Matematika, 1(1), 45-51. journal.unj.ac.id/unj/index.php/jrpmj/article/download/4961/3659

Selçuk, G. S., Sahin, M., \& Açikgöz, K. Ü. (2010). The Effects of Learning Strategy Instruction on Achievement, Attitude, and Achievement Motivation in a Physics Course. Research in Science Education, 41(1), 39-62. https://doi.org/10.1007/s11165-009-9145-x

Tan, L. S., \& Ang, K. C. (2016). A school-based professional development programme for teachers of mathematical modelling in Singapore. Journal of Mathematics Teacher Education, 19(5). https://doi.org/10.1007/s10857-015-9305-z

Thachasongtham, D., Yoshida, T., Sorbier, F. de, \& Saito, H. (2013). 3D Object Pose Estimation Using Viewpoint Generative Learning. Scandinavian Conference on Image Analysis (SCIA), 512-521. https://doi.org/10.1007/978-3-642-38886-6_48

Umam, K., Nusantara, T., Parta, I. N., Hidayanto, E., \& Mulyono, H. (2019). An Application of Flipped Classroom in Mathematics Teacher Education Programme. International Journal of Interactive Mobile Technologies (IJIM), 13(03), 68. https://doi.org/10.3991/ijim.v13i03.10207

Wena, M. (2012). Strategi Pembelajaran Inovatif Kontemporer: Suatu Tinjauan Konseptual Operasional. Bumi Aksara.

Wittrock, M. C. (1974). Learning as a generative process1. Educational Psychologist, 11(2), 87-95. https://doi.org/10.1080/00461527409529129

Yoshida, T., Saito, H., Shimizu, M., \& Taguchi, A. (2013). Stable keypoint recognition using viewpoint generative learning. Proceedings of the 8th International Conference on Computer Vision Theory and Applications (VISAPP), 310-315.

Yuningsih, N., Nursuprianah, I., \& Manfaat, B. (2021). Eksplorasi Etnomatematika pada Rancang Bangun Rumah Adat Lengkong. Jurnal Riset Pendidikan Matematika Jakarta, 3(1), 1-13.

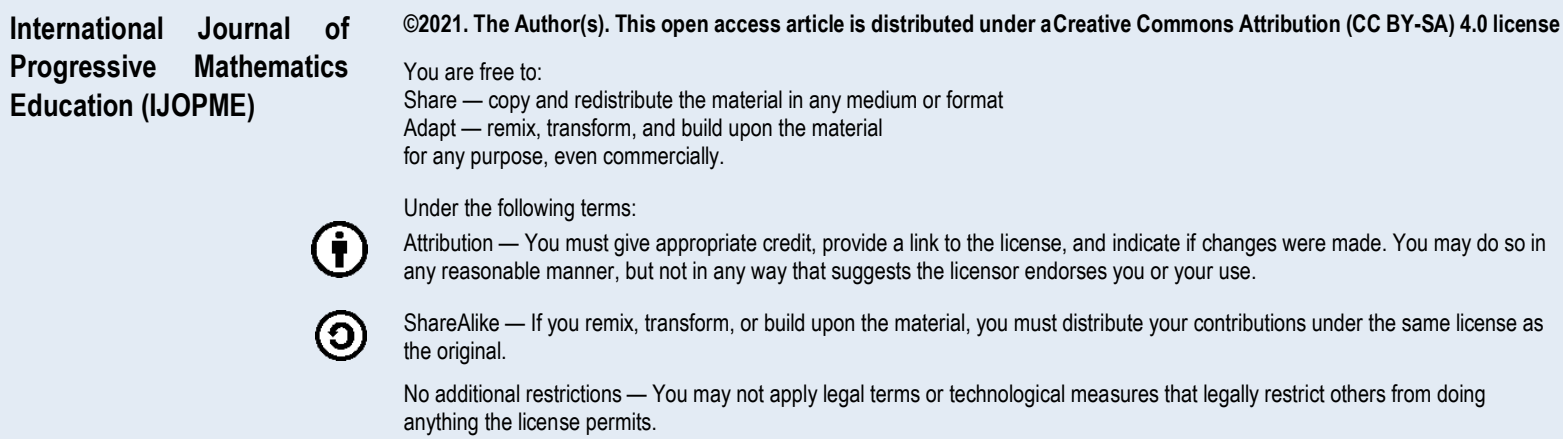

(2) ShareAlike - If you remix, transform, or build upon the material, you must distribute your contributions under the same license as the original.

No additional restrictions - You may not apply legal terms or technological measures that legally restrict others from doing anything the license permits. 